\title{
Increase in the Chlorophyll Contents by Over-expression of GmNAP1 Gene in Arabidopsis Plant
}

\author{
Phun Bum Park* and Chul-Hyun Ahn
}

Department of Bioscience and Biotechnology, University of Suwon, Hwasung 445-743, Korea

Received September 12, 2010 / Accepted October 2, 2010

\begin{abstract}
In the course of a research concerning the molecular mechanism of hypocotyl elongation that occurs during soybean seedling growth in darkness, we have generated a number of ESTs from a cDNA library prepared from the hypocotyls of dark-grown soybean seedlings. Comparison of the ESTs assigned a cDNA clone as a putative plastidic ATP-binding-cassette (ABC) protein homologue. The soybean GmNAP1 protein contains an N-terminal transit peptide which targets it into the chloroplast. The transcription level of the GmNAP1 gene was investigated under continuous red light, continuous far-red light, and complete darkness. The main function of this NAP1 protein is the transport of protoporphyrin IX which is the precursor of chlorophyll from the cytoplasm to the chloroplast. The GmNAP1 gene was transferred into the Arabidopsis under the CaMV 35 S promoter. The chlorophyll level of this transgenic Arabidopsis plant was much higher than the chlorophyll level of the wild type Arabidopsis plant.
\end{abstract}

Key words : Nonintrinsic ABC protein, chlorophyll, protoporphyrin X, soybean

\section{서 론}

식물은 다른 생명체와 달리 세 가지의 유전체를 함유하고 있다. 핵 유전체, 미토콘드리아 유전체, 그리고 엽록체 유전체 이다. 특히 식물의 광합성을 담당하고 있는 엽록체와 핵과의 신호전달에 많은 관심이 증가되고 있다. 엽록체 단백질 중 $90 \%$ 이상이 핵 유전체에 의해 coding되고 세포질에서 단백질 합성된 후 엽록체로 이동 한다[4]. 또한 많은 수의 핵 유전체 coding 단백질들이 엽록체 유전자의 전사 및 번역을 조절하고 있다. 최근 연구 결과에 의하면 엽록체에서 기원한 신호가 핵 및 세포 전체에 영향을 미치는 경우가 보고 된 바 있다[2].

$\mathrm{ABC}$ (ATP-binding cassette) 단백질은 용매 수송에 관여하 는 단백질로써 모든 진핵생물에 존재하는 것으로 밝혀졌다[3]. 이 단백질은 2 개의 $\mathrm{ATP}$ 결합 영역과 2개의 막 관통 영역이 존재한다. $\mathrm{ABC}$ 단백질은 애기장대와 벼에서 120 개 이상이 존 재하는 superfamily로 구성되어있는 단백질 그룹 중 하나이고 nucleotide 결합 영역과 막 관통 영역을 가지고 있는 것으로 밝혀졌다[1,11,12]. 이들은 옥신을 이동시키거나, 지방분해, 기 공 조절, 질병에 대해 저항성을 나타내는 기능을 나타내고 있 다. 식물 $\mathrm{ABC}$ 단백질 중에서 한 개의 ATP 결합 영역이 존재하 며, 막 관통 영역이 존재하지 않는 구조로 되어있는 일련의 단백질이 존재한다. 이러한 구조의 단백질은 애기장대에서 26 개, 벼에서 16 개 존재하는 데 이들을 일반적인 $\mathrm{ABC}$ 와 구별하 기 위해 nonintrinsic $\mathrm{ABC}$ protein (NAP)이라고 한다[12]. 이

*Corresponding author

Tel : +82-31-220-2236, Fax : +82-31-220-2519

E-mail : pbpark@suwon.ac.kr
들 NAP들은 원핵생물에 많이 존재하는 $\mathrm{ABC}$ transporter의 $\mathrm{ATP}$ 결합 소단위체와 유사성을 보이고 있다.

AtNAP1 (AtABC1)은 엽록소의 전구물질인 protoporphyrin IX의 엽록체로의 전달에 관여하며 또한 phytochrome 신호전달에 관여하는 색소체 단백질이다[7]. AtNAP1 이 결실된 laf6 (long after FR) 돌연변이체에서는 AtNAP1 기 능이 결여되어 엽록소의 전구체인 protophopyrin IX이 다량 축적되며 또한 지속적인 원적색광에 의해 조절되는 유전자의 발현도 감소되었다. 이러한 엽록소의 전구물질이 핵과 엽록체 사이에서 빛에 관여하는 신호로 작용한다는 사실이 최근 밝혀 졌다[5,14]

또한 AtNAP1는 원핵생물의 SufB 단백질과 상당히 유사한 것으로 밝혀졌다[16]. 원핵생물의 SUF 시스템의 역할은 산화 스트레스 상태에서 철-황 복합체(Fe-S clusters)의 합성과 수선 에 관여하는 중요한 기능을 수행하는 것으로 밝혀졌다. SUF 단백질은 SufA, SufB, SufC, SufD, SufS, SufE 총 6개의 단백질 로 구성되어있다[15]. 이중 SufC는 $\mathrm{ABC}$ protein으로 SufB 와 SufD 와 복합체를 이루면서 SUF 시스템에서 가장 중요한 기 능을 수행하는 것으로 밝혀졌다 $[6,8,10]$. SufB와 SufD의 기능 에 대해서는 아직 알려진 바가 없다. 또한 최근에 원핵생물의 $\mathrm{SufC}$ 와 상동성이 높은 유전자를 애기장대에서 분리하였고 이 를 AtNAP7이라고 명명하였다[17]. AtNAP1가 SufB의 기능을 하는 것으로 나타났는데 이것은 SufB 유전자가 결실된 대장균 에 AtNAP1 유전자를 전이하면 산화성 스트레스를 처리 하였 을 때 보완되는 현상으로 알 수 있었다[16]. 미생물 SufB와는 달리 AtNAP1은 철에 의해 증가되는 ATPase 기능을 나타내고 있고 homodimer 형태로 구성되어 있다. AtNAP1의 활성과 
유전자의 발현이 철의 농도에 의해 조절되기 때문에 AtNAP1 이 색소체내에서 철의 항상성에 관여한다고 볼 수 있다[16]. 본 연구에서는 암(dark) 상태에서 성장한 대두 하배축에서 특이적으로 발현하는 ESTs에 관한 유전체 분석을 하는 과정에 서 애기장대의 AtNAP1과 아미노산 서열이 유사한 하나의 EST를 발견하였고 이 clone의 전체 염기서열을 결정하여 $G m N A P 1$ 유전자를 분리하였다. GmNAP1도 AtNAP1과 같이 엽록체 단백질임을 확인하였고 $\mathrm{GmNAP1}$ 이 과 발현된 애기장 대 형질전환체를 제작하여 엽록소 함량을 측정하였다.

\section{재료 및 방법}

\section{식물재료 및 RNA 분리 및 cDNA library 제작}

대두를 MS (Murashige \& Skoog)배지에서 키우기 위해 먼 저 70\% ethanol로 3분간 소독하였고 ethanol을 제거한 후 30\% 락스로 3 분간 더 소독하였다. 소독된 대두를 distilled water로 5 번 정도 깨끗이 씻어 $4^{\circ} \mathrm{C}$ 에서 하루 정도 방치하였다. 이후 phytagel (Sigma, MO, USA) 5\%가 첨가된 MS medium에 치 상하였고 Plant Growth Chamber를 이용하여 암 상태 $20^{\circ} \mathrm{C}$ 에 서 6일간 키웠다. RNA를 분리하기 위해서 조직을 Grinding Mixer Mill MM301 (Retsch, Haan, Germany)을 사용하여 분 쇄하였고 TRIZOL reagent (BRL)을 이용하여 RNA를 분리하 였다. poly $(\mathrm{A})+\mathrm{RNA}$ 를 분리 후 cDNA synthesis kit (Stratagene)을 이용하여 cDNA library를 제작하였다

\section{EST sequence와 cDNA sequence 확인}

$\mathrm{ESTs}$ 에서 AtNAP1과 아미노산 서열이 유사한 EST가 존재 하는 것을 NCBI (http://www.ncbi.nln.gov)에서 제공하는 blast search program을 통해 확인한 후 이 clone의 전체 염기 서열을 확인하였다. 염기서열 확인 결과 개시 codon과 종결 codon이 존재하는 full-length sequence를 가지고 있는 clone 임이 확인되었다.

\section{Alignment와 Phylogenetic tree}

$\mathrm{GmNAP} 1$ 과 기존에 알려져 있는 $\mathrm{ABC}$ 단백질과의 유사성 을 확인하기 위해 bioedit sequence alignment editor 프로그 램을 사용하여 clustalW multiple alignment를 실행하였다. 또 한 (http://www.expasy.org/)에서 제공하는 단백질 분석 tool (Robust Phylogenetic Analysis For The Non-Specialisthttp://www.phylogeny.fr-)을 이용하여 계통도를 만들었다.

\section{$\mathrm{RT}-\mathrm{PCR}$ 분석}

대두를 적색광(red light), 원적색광(far-red light), 암(dark) 상태에서 6일 동안 키운 후 시간 별로 채취한 sample을 Grinding Mixer Mil로 분쇄한 뒤 각각의 seedling에서 total $\mathrm{RNA}$ 를 분리하였다. 추출한 total RNA를 역전사시켜 cDNA
를 합성하기 위해서 total volume $25 \mu \mathrm{l}$ 안에 정량 된 RNA $3 \mu \mathrm{g}$, Oligo (dT) $18 \mathrm{mer}(10 \mathrm{pmol})$, dNTP $(2.5 \mathrm{mM}), 10 \times$ reaction buffer, reverse transcriptase를 혼합하여 $37^{\circ} \mathrm{C}$ 에서 반 응시켰다. GmNAP1 cDNA를 detection할 수 있는 primer를 제작하고 합성된 cDNA를 template로 하여 PCR을 수행하였 다(Specific gene primer F-5'-AAGGCCTTGGATAAATTC-3' R-5'-CACCTGCGTCCACGATAT-3', Actin primer F-5'-CT TGTATGCAAGTGGTCG-3' R-5'-TCCTTGCTCATACGGTC $\left.\mathrm{T}-3^{\prime}\right)$.

\section{GFP fusion protein vector 제작}

대두 GmNAP1 cDNA 중 엽록체로 향하게 하는 transit peptide인 N-terminal 70개 아미노산의 coding sequence를 PCR 로 증폭하여 GFP coding region의 앞부분에 fusion시켜서 PEG를 이용하여 애기장대에 형질전환 한 후 GFP가 어디서 발광하는가를 confocal microscopy로 확인하였다. 미토콘드 리아 표적 여부를 확인하기 xxRFP를 대조구로 사용하였다

\section{애기장대 형질전환체 제작}

대두 GmNAP1 cDNA의 coding region을 PCR로 증폭한 후 형질전환 vector인 pCAMBIA 1300에 cloning하였다. 이 재조 합 DNA를 Agrobacterium에 형질전환 한 후 애기장대에 다시 형질전환 하여 형질전환체를 확보하였다.

\section{엽록소 함량 측정}

Dimethylsulphoxide (DMSO)를 사용하여 생체 $100 \mathrm{mg}$ 과 $100 \%$ DMSO $10 \mathrm{ml}$ 를 시험관에 넣은 후 $65^{\circ} \mathrm{C}$ 수조에서 6시간 중탕 후 추출하여 측정하였다. 엽록소 함량은 spectrophotometer를 사용하여 $648 \mathrm{~nm}$ 와 $665 \mathrm{~nm}$ 에서 측정하였으며 다 음 식을 이용하여 엽록소 함량을 구하였다[14].

$$
\begin{aligned}
& \mathrm{C}=\mathrm{Ca}+\mathrm{Cb}=20.2 \mathrm{~A} 648+8.02 \mathrm{~A} 665 \\
& \mathrm{C} \text { : chlorophyll concentration }(\mathrm{mg} / \mathrm{l}) \\
& \mathrm{Ca} \text { : chlorophyll a } \mathrm{Cb} \text {; chlorophyll b } \\
& \text { A: absorbance in } 1 \mathrm{~cm} \text { cuvettes }
\end{aligned}
$$

\section{결과 및 고찰}

\section{GmNAP1 cDNA 분리 및 GmNAP1 아미노산 서열 결정}

암(dark) 상태에서 키운 대두 하배축에서 구축한 ESTs 중 AtNAP1와 아미노산 서열의 상동성이 높은 clone을 선발하여 full-length sequence를 확인하였다. 이 clone의 $\mathrm{ORF}$ 의 크기 는 $1593 \mathrm{bp}$ 이고 530개의 아미노산으로 구성되었다. $\mathrm{GmNAP1}$ 의 아미노산 서열과 연관된 식물 NAP와 미생물 단 백질과 alignment를 수행하였다(Fig. 1). GmNAP1은 AtNAP1와 약 $80 \%$ 의 높은 상동성을 보이므로 유사한 기능을 
(gnaBC) soybean

(atABC1) arabidopsis

(os $A B C$ ) Oryza sativa

(synABC) Synechococcus sp.

(porphyraaBC) Porphyra purpure

(Protein sufB, putative) Ricin

(non-intrinsic $\mathrm{ABC}$ protein)

(iron-sulfur cluster assembly

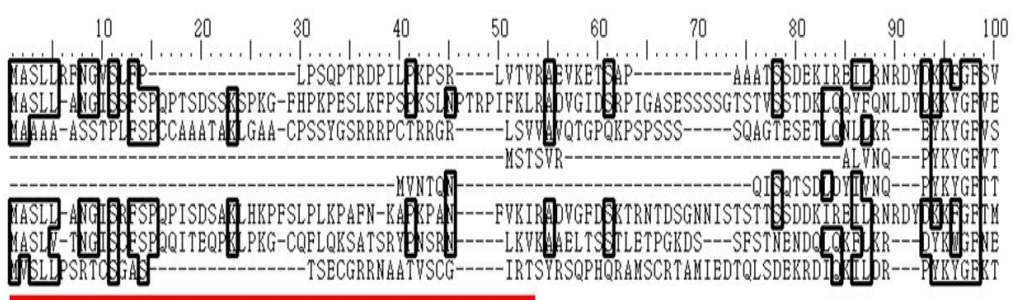

(gmABC) sogbean

(atABC1) arabidops is

(os $\mathrm{BCC}$ ) Oryza sativa

(synABC) Synechococcus $s p$

(porphyraABC) Porphyra purpure

(Protein sufB, putative) Ricin

(non-intrinsic $A B C$ protein) $\mathbb{N i}$

(iron-sulfur cluster assembly

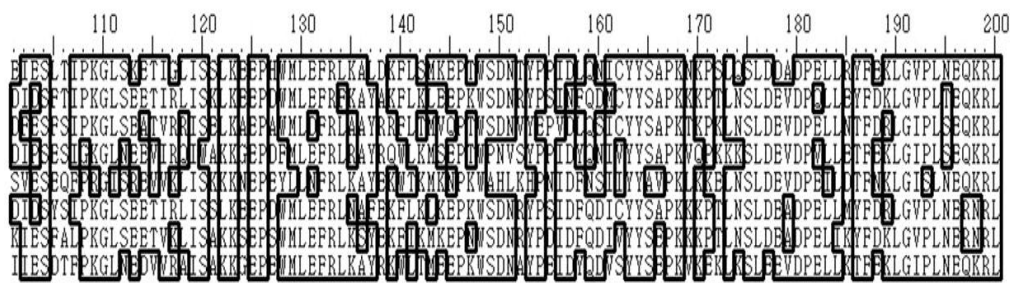

(gmABC) sogbean

(ataBC1) arabidopsis

(osABC) Oryza sativa

(synABC) Synechococcus $\mathrm{sp}$.

(porphyraaBC) Porphyra purpure (Protein sufB, putative) Ricin (non-intrinsic $A B C$ protein) $\mathbb{N}$

(iron-sulfur cluster assembly

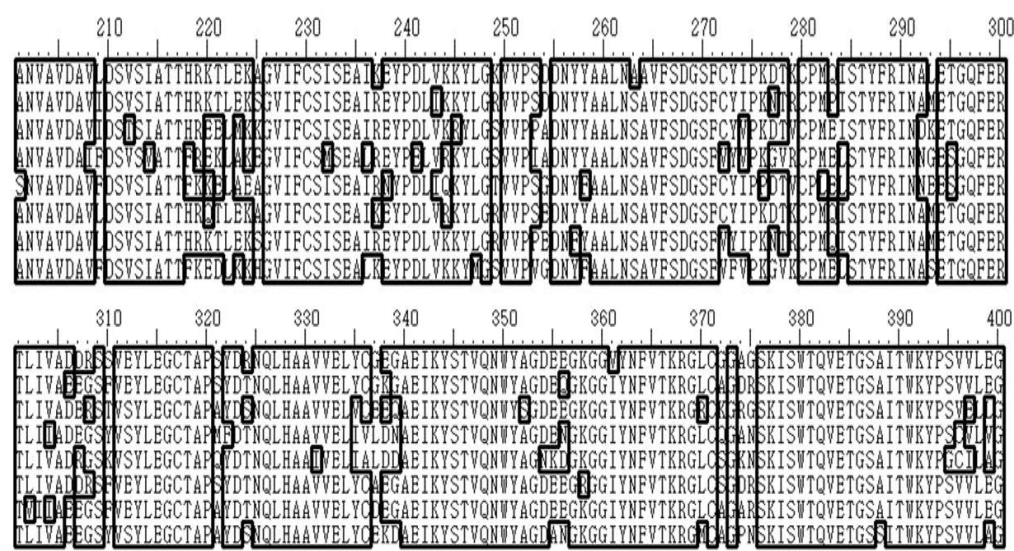

$$
\begin{aligned}
& \text { ( } \mathrm{gmABC} \text { ) soybean } \\
& \text { (at } A B C 1) \text { arabidopsis } \\
& \text { (osABC) Oryza sativa } \\
& \text { (synABC) Synechococcus sp. } \\
& \text { (porphyraABC) Porphyra purpure } \\
& \text { (Protein suf } B \text {, putative) Ricin } \\
& \text { (non-intrinsic ABC protein) Ni } \\
& \text { (iron-sulfur cluster assembly }
\end{aligned}
$$
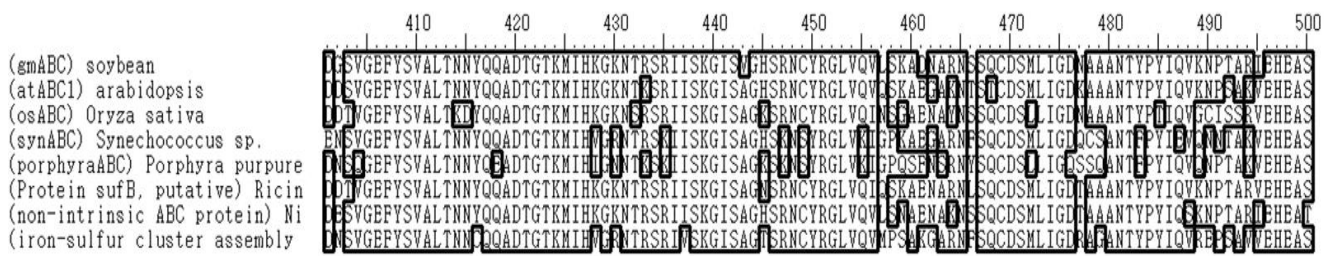

(gnaBC) soybean

(at $A B C 1)$ arabidops is

(os $A B C)$ Oryza sativa

(synABC) Synechococcus $s p$.

(porphyraABC) Porphyra purpur

(Protein sufB, putative) Ricin

(non-intrinsic $\mathrm{ABC}$ protein) $\mathrm{Ni}$

(iron-sulfur cluster assembl

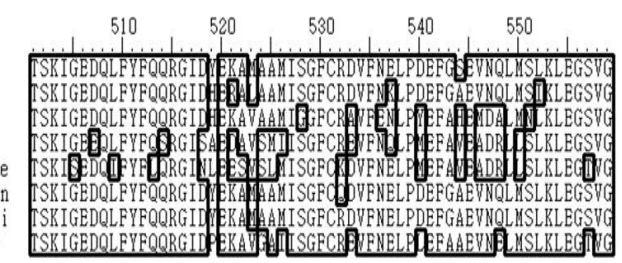

Fig. 1. Amino acid sequence alignment of GmNAP1 with related amino acid sequences from plants and bacteria. The following sequences are aligned: GmNAP1, AtNAP1 from Arabidopsis (GenBank accesion No. AAD03441), OsNAP1 from Oryza sativa (NP_915325), Synechocystis sp. (synABC), Porphyra (porphyraABC), Volvox carteri f. nagariensis (iron-sulfur cluster assembly protein), Nicotiana benthamiana (non-intrinsic ABC protein) and Ricinus communis (Protein sufB, putative). The transit peptide to the chloroplast is in red.

할 것으로 예측되며 원핵생물의 SufB 단백질과도 매우 유사 하게 나타났다. 원핵생물의 SufB 단백질과 유사한 것은 아마 도 식물의 색소체 $\mathrm{ABC}$ 단백질의 기원이 세포내 공생설 결과 인 것으로 예측된다[10]. 식물 NAP 단백질과 원핵생물 SufB와 의 차이점은 N-terminal에 엽록체로 향하는 target signal pep- tide의 존재 유무로 구별된다(Fig. 1 red-bar). 이들의 계통도를 그려 보았더니 GmNAP1은 Ricinus SufB와 가장 상동성이 높 은 것으로 나타났고 같은 쌍자엽식물 NAP들은 한 개의 group을 형성하였다(Fig. 2). 


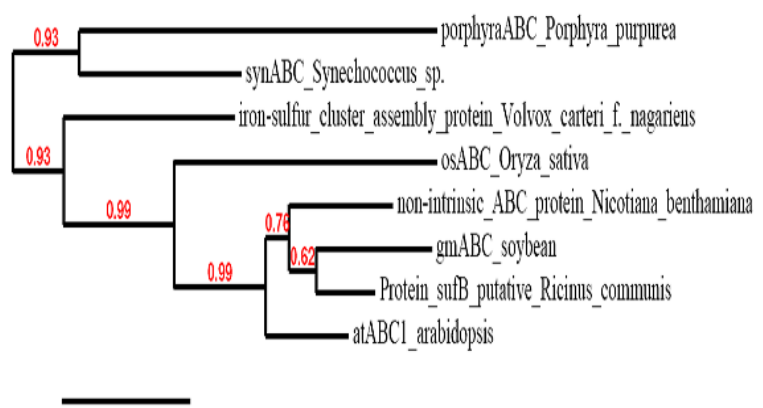

0.1

Fig. 2. Phylogenetic analysis of the GmNAP1 protein with the related amino acid sequences from plant and bacteria. The phylogenetic tree was constructed using MEGA software version 4.0 via the neighbor-joining method. The numbers in the branches are the bootstrap values expressed as percentages. Bootstrap analysis was performed with 1,000 replicates and bootstrap values are shown as percentages.

\section{원적색광과 적색광에 의한 $\mathrm{GmNAP1}$ 유전자의 발현량 변} 화 측정

애기장대의 경우 AtNAP1 유전자의 발현이 암 상태에서는 기저수준으로 발현되고 높은 원적생광을 $18 \mathrm{hr}$ 처리하여 주면 2 배 정도 발현량이 증가하는 것으로 관찰되었으나 적색광을 $18 \mathrm{hr}$ 처리하면 발현량의 변화가 거의 없는 것으로 관찰되었 다[7]. 이와 비교하기 위해 대두를 암 상태에서 6 일간 키운 후 높은 세기의 적색광과 원적생광을 $3 \mathrm{hr}, 6 \mathrm{hr}, 18 \mathrm{hr}$ 처리하 고 RT-PCR을 수행하여 GmNAP1 유전자의 전사 pattern을 조 사하였다. Fig. 3에서 보는 바와 같이 대두의 경우 암 상태, 적색광 처리 후 그리고 원적색광 처리 후의 경우 모두가 비슷

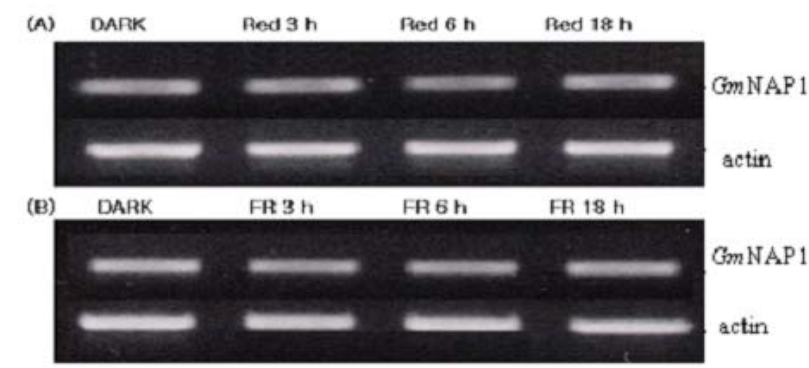

Fig. 3. GmNAP1 transcripts analysis by RT-PCR. A: Expression profiles of the soybean chloroplast GmNAP1 transcripts in darkness $(6 \mathrm{~d}$, lane 1$)$, and in response to high fluence red light irradiation for $3 \mathrm{hr}$ (lane 2), $6 \mathrm{hr}$ (lane 3), and $18 \mathrm{hr}$ (lane 4). The bottom part is actin transcripts analysis as a control. B: Expression profiles of the soybean chloroplast GmNAP1 transcripts in darkness (6 d, lane 1), and in response to high fluence far-red light irradiation for $3 \mathrm{hr}$ (lane 2), $6 \mathrm{hr}$ (lane 3), and $18 \mathrm{hr}$ (lane 4). The bottom part is actin transcripts analysis as a control.
한 발현량을 나타내고 있다. 즉 대두에서는 GmNAP1 유전자 의 발현이 애기장대와 같이 근적외광에 의하여 크게 유도가 되지 않는 다는 점이다. 또한 GmNAP1의 기능이 엽록소의 전구물질인 protophoryin IX의 엽록체로의 전달에 관여하는 것으로 밝혀졌는데 빛이 없는 암 상태에서도 발현이 된다는 사실은 암 상태에서는 또 다른 물질의 수송에도 관여하는 것 으로 사료되는 바이다.

\section{GmNAP1의 세포 내 위치 확인}

GmNAP1의 세포 내 위치를 실험적으로 확인하기 위하여 이 단백질을 엽록체로 향하게 하는 역할을 하는 signal peptide 70개 아미노산의 coding region을 PCR로 증폭한 후 green fluorescent protein (GFP)와 접합시켰다. 이를 PEG를 이용하여 애기장대 원형질체에 형질전환 한 후 confocal microscopy로 관찰하였다. 미토콘드리아의 위치를 확인하기 위 하여 미토콘드리아 위치를 확인하여 주는 $\mathrm{xxRFP}$ 를 대조구로 사용하였다. 실험결과 $\mathrm{GmNAP} 1$ 은 엽록체에 존재하는 것으로 확인되었고 미토콘드리아로는 targeting되지 않는 것으로 확 인되었다(Fig. 4).

GmNAP1 유전자 애기장대에 과 발현 후 엽록소 함량 측정 GmNAP1 유전자를 애기장대에 형질전환하여 대량발현 후 엽록소 함량을 측정하여 보았다. NAP1이 엽록소의 전구물질 인 protoporphyrin IX의 엽록체로의 전달에 관여하는 것으로

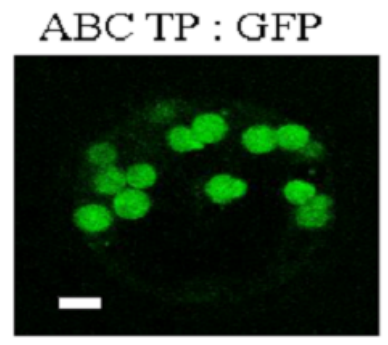

Bright

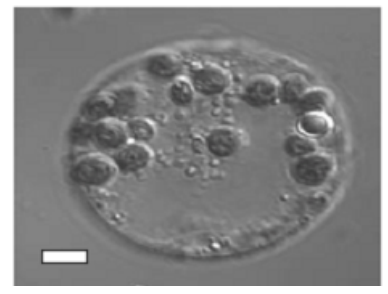

Mitochondria

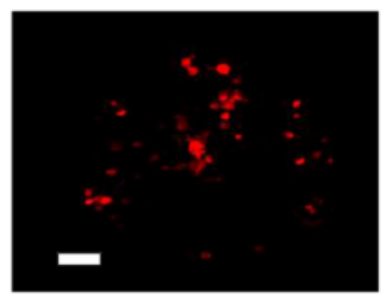

Merged

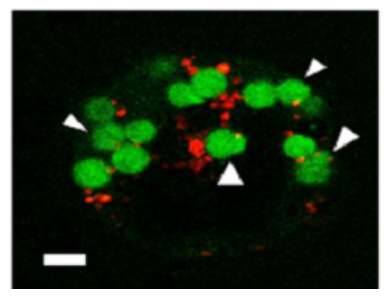

Fig. 4. Subcellular localization of GmNAP1 protein. In vivo targeting of fusion protein. Protoplast were transformed with P35S:ABC-TP:GFP:Tnos. Green fluorescent signals were examined $24 \mathrm{hr}$ to $30 \mathrm{hr}$ after transformation. Data are representative of transformed protoplasts. At least two independent transformation experiments were performed with each construct. 
Table 1. Chlorophyll contents of wild type and GmNAP1 over-expression Arabidopsis plant

$(\mathrm{mg} / \mathrm{l})$

\begin{tabular}{lcccc}
\hline & Grown in red light for 10 days & Grown in & far red light for 10 days & Grown in dark for 10 days \\
\hline Wild type & 1.69 & 0.245 & 0.06 \\
GmNAP1 OX plant & 2.607 & 0.635 & 0.267 \\
\hline
\end{tabular}

밝혀져 GmNAP1이 애기장대에서 대량발현 되면 엽록소 함량 이 증가할 것으로 예상하였고 예상대로 암 상태에서 성장한 경우 4.3 배, 적색광에서 성장한 경우는 1.5 배, 원적색광에서 상 장한 경우는 2.6 배 엽록소 함량이 같은 조건의 야생형보다 증가 하였다(Table 1). 엽록체 막에 존재하는 protophophyrinogen IX oxidase (PPO)에 의해 protophophyrinogen IX이 산화되어 protoporphyrin IX이 되어 NAP1에 의해 엽록체 stroma로 이 동하여 엽록소가 합성되는 것이다[7]. 그러므로 GmNAP1 유 전자와 $\mathrm{PPO}$ 유전자를 동시에 애기장대에 형질전환 시킨다면 엽록소 함량이 훨씬 더 증가할 것으로 사료되는 바이다. 또한 protoprophyrin IX는 핵과 엽록체 사이의 신호전달자 역할을 한다고 사료되는 바이다[5,16].

\section{References}

1. Dassa, E. and P. Bouige. 2001. The ABC of ABCs: a phylogenetic and functional classification of $\mathrm{ABC}$ systems in living organisms. Res. Microbiol. 152, 211-229.

2. Hedtke, B., I. Wagner, T. Borner, and W. R. Hess. 1999. Inter-organellar crosstalk in higher plants: impaired chloroplast development affects mitochondrial gene and transcript levels. Plant J. 19, 635-643.

3. Holland, B. I. and M. A. Blight. 1999. ABC-ATPases, adaptable energy generators fuelling transmembrane movement of a variety of molecules in organisms from bacteria to humans. J. Mol. Biol. 293, 381-399.

4. Keegstra, K. and K. Cline. 1999. Protein import and routing systems of chloroplasts. Plant Cell 11, 557-570.

5. Larkin, R. M., J. M. Alonso, J. R. Ecker, and J. Chory. 2003. GUN4, a regulator of chlorophyll synthesis and intracellular signaling. Science 299, 902-906.

6. Loiseau, L., S. Ollagnier-de-Choudens, L. Nachin, M. Fontecave, and F. Barras. 2003. Biogenesis of Fe-S cluster by the bacterial Suf system: SufS and SufE form a new type of cysteine desulfurase. J. Biol. Chem. 278, 38352-38359.

7. Møller, S. G., T. Kunkel, and N. H. Chua. 2001. A plastidic $\mathrm{ABC}$ protein involved in intercompartmental communication of light signaling. Genes Dev. 15, 90-103.

8. Nachin, L., L. Loiseau, D. Expert, and F. Barras. 2003. SufC: an unorthodox cytoplasmic ABC/ATPase required for [Fe-S] biogenesis under oxidative stress. EMBO J. 22, 427-437.

9. Osteryoung, K. W. and J. Nunnari. 2003. The division of endosymbiotic organelles. Science 302, 1698-1704.

10. Rangachari, K., C. T. Davis, J. F. Eccleston, E. M. A. Hirst, and J. W. Saldanha. 2002. SufC hydrolyzes ATP and interacts with SufB from Thermotoga maritima. FEBS Lett. 74, 225-228.

11. Rea, P. A. 2007. Plant ATP-Binding Cassette Transporters. Annu. Rev. Plant Biol. 58, 347-375.

12. Sánchez-Fernández, R., T. G. E. Davies, J. O. D. Coleman, and P. A. Rea. 2001. The Arabidopsis thaliana ABC protein superfamily, a complete inventory. J. Biol. Chem. 276, 30231-30244.

13. Seo, K. Y, Y. H. Son, and J. W. Koo. 2005. Extraction and determination of chlorophyll contents of Korean pine needles using acetone and DMSO (dimethylsulfoxide). J. Korean For. Soc. 4, 264-268.

14. Strand, A., T. Asami, J. Alonso, J. R. Ecker, and J. Chory. 2003. Chloroplast to nucleus communication triggered by accumulation of Mg-protoporphyrin IX. Nature 421, 79-82.

15. Takahashi, Y. and U. Tokumoto. 2002. A third bacterial system for the assembly of iron-sulfur clusters with homologs in archaea and plastids. J. Biol. Chem. 277, 28380-28383.

16. Xu, X. M., S. Adams, N. H. Chua, and S. G. Møller. 2005. AtNAP1 represents an atypical SufB protein in Arabidopsis plastids. J. Biol. Chem. 280, 6648-6654.

17. Xu, X. M. and S. G. Møller. 2004. AtNAP7 is a plastidic SufC-like ATP-binding cassette/ATPase essential for Arabidopsis embryogenesis. Proc. Natl. Acad. Sci. 101, 91439148. 


\section{초록 : 애기장대에서 $G m N A P 1$ 의 과발현으로 인한 엽록소 함량 증가}

\section{박훤범* · 안철현}

(수원대학교 생명공학과)

암(dark) 상태에서 재배한 대두의 하배축 길이 생장의 분자 기작을 연구하기 위한 일환으로 암 상태에서 재배한 대두 하배축으로부터 cDNA library를 제작한 후 ESTs를 구축하였다. 이들 ESTs 중 색소체 ABC 단백질과 아미노 산 서열이 매우 유사한 clone을 선발한 후 이 유전자의 전체염기서열을 결정하였다. GmNAP1 단백질은 엽록체로 향하는 transit peptide 서열이 존재한다. 빛에 의해 GmNAP1 유전자 전사가 어떻게 변화되는지 알아보기 위해 지속적인 적색광, 근적색광 그리고 암 상태에서 성장시키면서 유전자의 전사량을 확인하였다. 이 색소체 NAP1는 엽록소의 전구 물질인 protoporphytin IX를 세포질에서 엽록체로 이동시키는 기능을 한다. 대두에서 분리된 $G m N A P 1$ 유전자의 기능을 확인하기 위하여 $35 S$ 프로모터 뒤에 GmNAP1 유전자를 접합한 후 애기장대에 형질전 환하였다. 형질전환 된 애기장대의 엽록소 함량은 야생형의 엽록소 함량보다 훨씬 높게 측정되었다. 